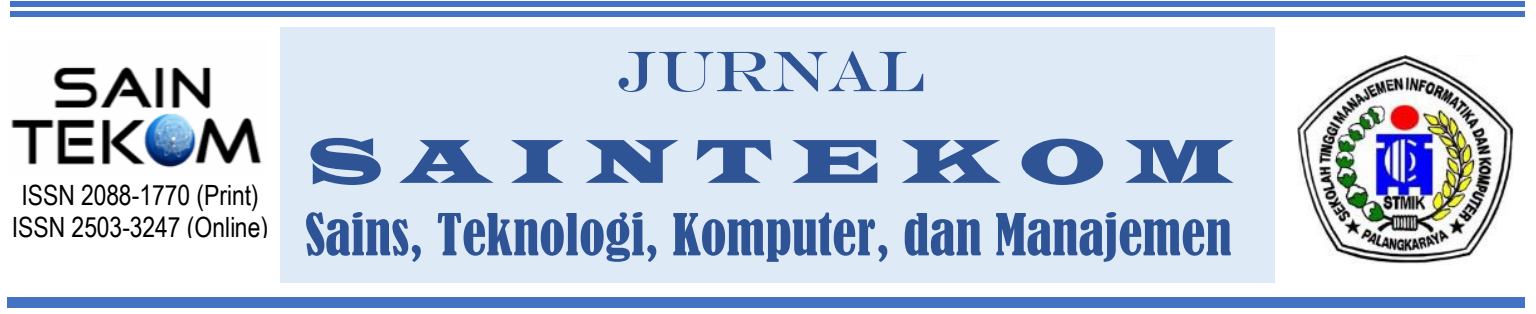

\title{
FORENSIK MULTIMEDIA BERBASIS MOBILE MENGGUNAKAN METODE NATIONAL INSTITUTE OF JUSTICE
}

\author{
Imam Riadi ${ }^{1}$, Sunardi ${ }^{2}$, ${ }^{*}$ Takdir Ruslan ${ }^{3}$ \\ 1) Program Studi Sistem Informasi, Universitas Ahmad Dahlan \\ 2) Program Studi Teknik Elektro, Universitas Ahmad Dahlan \\ 3) Program Studi Teknik Informatika, Universitas Ahmad Dahlan \\ Jl. Prof. Dr. Soepomo Umbulharjo, Kota Yogyakarta 55164 \\ Email: imam.riadi@is.uad.ac.id, sunardi@mti.uad.ac.id, \\ takdir1908048028@webmail.uad.ac.id
}

\begin{abstract}
Current technological developments make it easier for people to share information and carry out communication activities through instant messaging applications using multimedia features in the form of audio and video. Technology has been able to contribute and facilitate humans in a positive sense, but it can also be misused to carry out negative activities. In solving crime problems using instant messages, investigators need to carry out digital forensics, including on mobile devices such as smartphones. This study aims to obtain digital evidence of online drug sales scenarios via Facebook messenger and WhatsApp using four forensic tools, namely Belkasoft, Oxygen, MOBILedit, and Magnet Axiom. The National Institute of Justice (NIJ) is used as a framework with stages, namely identification, solution, testing, evaluation, and reporting of results. out of the four tools, MOBILedit cannot recover deleted audio and video while the other three tools can recover deleted audio and video.
\end{abstract}

Keywords: Digital Evidence, Digital Forensics, Mobile Forensics, Multimedia Forensics, NIJ

\section{ABSTRAK}

Perkembangan teknologi saat ini memudahkan masyarakat untuk berbagi informasi dan melakukan aktivitas komunikasi melalui aplikasi pesan instan dengan menggunakan fitur multimedia berupa audio dan video. Teknologi telah mampu memberikan kontribusi dan kemudahan bagi manusia dalam arti positif, namun juga dapat disalahgunakan untuk melakukan aktivitas negatif. Dalam menyelesaikan masalah kejahatan menggunakan pesan instan, penyidik perlu melakukan forensik digital, termasuk pada perangkat mobile seperti smartphone. Penelitian ini bertujuan untuk mendapatkan bukti digital skenario penjualan obat secara online melalui Facebook messenger dan WhatsApp menggunakan empat alat forensik yaitu Belkasoft, Oxygen, MOBILedit dan Magnet Axiom. National Institute of Justice (NIJ) digunakan sebagai kerangka dengan tahapan yaitu identifikasi, solusi, pengujian, evaluasi dan pelaporan hasil. dari 
empat alat, MOBILedit tidak dapat memulihkan audio dan video yang dihapus sementara tiga alat lainnya dapat memulihkan audio dan video yang dihapus.

Kata Kunci : Bukti Digital, Forensik Digital, Forensik Mobile, Forensik Multimedia, NIJ

\section{PENDAHULUAN}

Perkembangan teknologi juga seiring dengan perkembangan Perangkat seluler yang mengalami peningkatan sangat pesat. (Zamroni et al., 2016). Pada saat ini peningkatan jumlah fitur dan aplikasi yang tersedia pada perangkat seluler bukan tidak mungkin smartphone akan menggantikan peran komputer (Umar et al., 2018).

Kemudahan berinteraksi di media sosial saat ini sangat banyak pengguna menggunakan fitur multimedia pada aplikasi instant messaging saat berkomunikasi atau bertukar pesan (Aditya \& Wardhana, 2016).

Aplikasi-aplikasi yang terdapat pada smartphone menjadi alternatif baru dalam bertukar pesan, layanan tersebut juga dapat melakukan pengiriman teks, audio, video atau gambar lebih muda dan cepat, menggunakan jaringan internet yang tentunya melalui telepon ataupun video call, yaitu pada aplikasi WhatsApp, Instagram, Line, dan Facebook Messenger .(Parlika \& Hutama, 2019) .
Menurut survey (Databoks, 2020), 98\% dari penduduk indonesia yang berinternet menggunakan smartphone dihabiskan dengan menggunakan aplikasi.

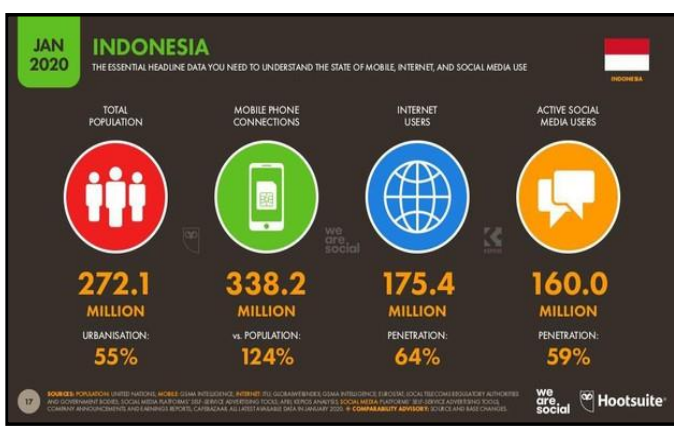

Gambar 1. Jumlah pengguna internet di Indonesia tahun 2020.

Gambar 1 menjelaskan Salah satu aplikasi yang banyak digunakan masyarakat adalah aplikasi instant messaging. (detiknet, 2020) menyebutkan terdapat 175,4 juta pengguna media sosial di Indonesia. Jumlah itu naik sekitar 25 juta pengguna dibandingkan dengan hasil riset pada tahun sebelumnya. Dalam laporan ini juga diketahui bahwa saat ini ada 160 juta pengguna aktif media sosial, masyarakat Indonesia yang menggunakan ponsel yaitu sebanyak 338,2 juta.

Peningkatan jumlah pengguna instant messaging dan perkembangan 
teknologi ternyata juga menimbulkan dampak negatif, yaitu dengan munculnya oknum-oknum yang menyalah gunakan aplikasi instant messaging untuk kejahatan digital atau cybercrime seperti penipuan, pornografi, dan penjualan narkoba (Bakti Kominfo, 2019).

Penelitian terdahulu yang relevan dengan penelitian ini dilakukan oleh (Widodo et al., 2018) dengan judul Analisis Forensik Digital Aplikasi Whatsapp Dan Facebook Messenger Pada Android Sebagai Barang Bukti Digital Dalam Penanganan Kasus Prostitusi Online, Penelitian ini menggunakan skenario percakapan terhadap kondisi aplikasi, diantaranya penghapusan percakapan pada aplikasi. Data diambil dan dianalisa menggunakan Oxygen Forensik dan Mobiledit Forensic Express Pro.

Penelitian (Yudhana et al., 2018) yang berjudul Analisis Bukti Digital Facebook Messenger Menggunakan Metode Nist. tools yang digunakan adalah Oxygen Forensik sedangkan Metode yang digunakan adalah metode NIST (National Institute of Standards Technology).

Proses investigasi forensik digital pada komputer atau perangkat sejenisnya dapat dilakukan dengan dua metode akuisisi, yakni metode live forensics dan static forensics (Sidiq \& Faiz, 2019). Pada langkah kerja forensik dapat mengimplementasikan salah satu kerangka kerja dan beberapa standar diantaranya National Institute of Standard and Technology (NIST), Integrated Digital Forensics Investigation Framework (IDFIF), National Institute of Justice (NIJ), dan Digital Forensics Research Workshop (DFWRS) (Nur Faiz et al., 2018).

\subsection{Forensik Digital}

Forensik digital merupakan bagian dari ilmu forensik yang melingkupi investigasi dan penemuan data yang ditemukan pada perangkat digital handphone, komputer, tablet, storage, networking devices dan sejenisnya (Raharjo, 2013).

\subsection{Forensik Mobile}

Forensik mobile adalah ilmu yang melakukan proses pemulihan bukti digital menggunakan cara yang sesuai dengan metode forensik dan kondisi dari perangkat seluler (Riadi et al., 2017). dengan adanya forensik untuk perangkat mobile dapat membantu mengatasi kasus kejahatan yang berhubungan dengan perangkat mobile khususnya smartphone karena 
Penggunaan mobile seperti smartphone dengan berbagai sistem operasi dan bermacam tipe untuk kejahatan sudah semakin tinggi jumlahnya seiring perkembangan teknologi pada saat ini (Faiz et al., 2016).

\subsection{Multimedia}

Multimedia merupakan

kombinasi teks gambar, video, animasi, yang dimanipulasi secara digital atau disampaikan melalui komputer dan dapat disampaikan atau dikontrol secara interaktif (Siregar \& Melani, 2019).

\subsection{Android}

Android adalah sistem operasi open source dengan sumber terbuka yang dirilis perusahaan Google di bawah lisensi Apache. Sifat sistem operasi Android yang open source memungkinkan sistem operasi ini untuk didistribusikan dan dimodifikasi secara bebas oleh para pengembang operator nirkabel, smartphone, dan pengembang aplikasi. (Asyaky, 2019)

Penelitian terdahulu (Riadi, Yudhana, et al., 2018) yang berjudul Akuisisi Bukti Digital Pada Instagram Messenger Berbasis Android Menggunakan Metode National Institute Of Justice (NIJ). Dalam penelitian ini Proses akuisisi data menggunakan tool Oxygen forensik untuk mendapatkan hasil sesuai dengan yang diinginkan, yakni barang bukti digital berupa percakapan/chatting dan gambar/foto dari sosial media Instagram yang terpasang pada smartphone tersebut.

Penelitian terdahulu (Riadi, Umar, et al., 2018) yang berjudul Analisis Forensik Digital Pada Frozen Solid State Drive Dengan Metode National Institute Of Justice (NIJ). Hasil yang di dapatkan Tidak semua file dapat direstorasi dengan baik karena struktur data dan file sudah rusak dan sejarah internet (history internet) tercatat ketika fitur pembeku drive diaktifkan serta catatan pengguna komputer (recent activity). pada penelitian ini menggunakan atau mengimplementasikan metode analisa forensik dari National Institute of Justice (NIJ). Metode ini untuk menjelaskan bagaimana tahapan penelitian yang akan dilakukan sehingga dapat diketahui alur dan langkah-langkah penelitian secara sistematis sehingga dapat dijadikan pedoman dalam menyelesaikan permasalahan yang ada.

Penelitian (Putra et al., 2017) yang berjudul Forensik Digital Pada Smartwatch Berbasis Android, Dari 
hasil akusisi berdasarkan dua tool tersebut,maka didapat keberhasilan hampir $100 \%$ dalam megumpulkan data-data yang ada berupa data kontak, sms, dan data panggilan yang ada di smartwatch. pada penelitian ini menggunakan dua tool yaitu Metasploit dan mobile edit.

\section{METODE}

Metode penelitian yang digunakan berdasarkan pedoman forensik perangkat mobile yang dibuat oleh National Institute of Justice (NIJ) dengan langkah-langkah sebagai berikut:

\subsection{Identifikasi}

Tahap identifikasi yaitu mengumpulkan informasi tentang masalah yang akan dihadapi dan mengidentifikasi masalah tersebut.

\subsection{Solusi}

Tahap solusi yaitu dari hasil identifikasi masalah dan informasi dari hasil tahap pertama kemudian mengajukan solusi yang mungkin untuk dilakukan dalam pemecahan masalah itu.

\subsection{Uji coba}

Tahap uji coba yaitu dari setiap solusi yang mungkin dilakukan untuk pemecahan masalah setelah mendapatkan solusi yang mungkin di lakukan dari tahap kedua, kemudian melakukan uji coba terhadap smartphone.

\subsection{Evaluasi}

Tahap evaluasi yaitu hasil yang di dapat dari hasil uji coba yang dilakukan dari setiap solusi agar di lakukan untuk pemecahan masalah kemudian melakukan evaluasi dari hasil tersebut.

\subsection{Laporan}

Tahap ini adalah tahap untuk melaporkan hasil yang di dapat dari pemecahan masalah untuk menyelesaikan prosedur dari setiap langkah yang telah di lakukan pada tahapan sebelumnya. Metode penelitian yang digunakan berdasarkan pedoman forensik perangkat mobile yang dikembangkan oleh National Institute of Justice ( NIJ ) dapat dilihat pada Gambar 2.

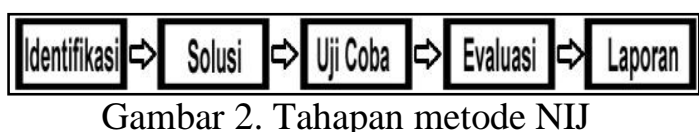

(Sumber : Riadi et al., 2019).

Simulasi ini dibuat untuk mendapatkan bukti digital yang kemudian dianalisis. Simulasi kasus berupa penjualan narkoba seperti pada Gambar 2 Tampak penjual narkoba menggunakan dua aplikasi instant messaging yang menawarkan dan 
menjual barang haram menggunakan fitur Multimedia yaitu Audio dan video tersebut ke pembeli.

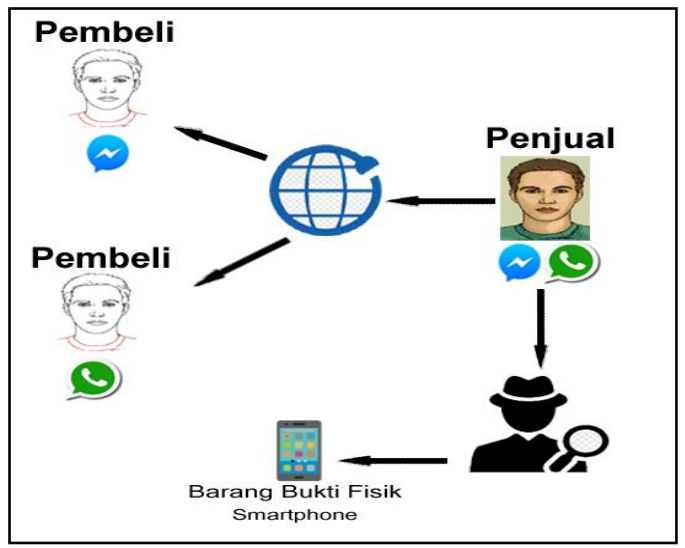

Gambar 3. Simulasi Kasus penjualan narkoba secara online

Gambar 3 menjelaskan bahwa Dalam percakapan pada aplikasi Facebook messenger dan WhatssApp di smartphone berbasis Android berupa Samsung J2 prime penjual mengirim Audio dan video, kemudian dilakukan penghapusan percakapan dari smartphone si penjual. Hal ini bertujuan menghilangkan barang bukti penjualan narkoba.

\section{HASIL DAN PEMBAHASAN}

Penelitian yang dilakukan dengan sebuah simulasi kasus percakapan pada aplikasi Facebook messenger dan WhatssApp di smartphone berbasis Android berupa Samsung J2 prime penjual mengirim Audio dan video, kemudian dilakukan penghapusan percakapan dari smartphone si penjual.

\subsection{Identifikasi}

Identifikasi merupakan tahapan paling awal dalam metode NIJ Mobile Forensik. pada Proses tahap ini yang dilakukan diantaranya adalah melakukan identifikasi permasalahan yang akan diselesaikan. Permasalahan dalam penelitian ini adalah bagaimana mengembalikan data atau proses forensik untuk multimedia berupa audio dan video yang telah dihapus pada smartphone yang akan dijadikan sebagai barang bukti. kemudian akan melakukan pendokumentasian dengan mencatat spesifikasi, model, merek, dan hal lain yang berkaitan dengan smartphone tersebut Setelah dilakukan identifikasi permasalahan yang dihadapi.

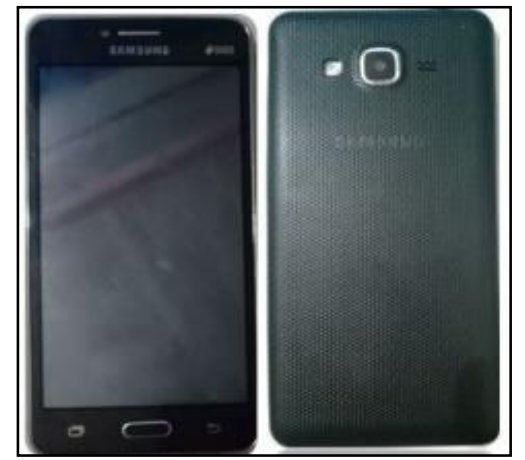

Gambar 4. Smartphone Penjual narkoba sebagai barang bukti

Gambar 4 adalah smartphone yang di jadikan barang bukti dalam kasus penjualan narkoba secara online. 


\subsection{Solusi}

$\begin{array}{ccc}\text { Tahap } & \text { berikutnya } & \text { adalah } \\ \text { mengajukan } & \text { solusi } & \text { untuk }\end{array}$ mengembalikan data yang telah dihapus dengan menggunakan empat tool forensik yaitu Belkasoft Evidence Center, Magnet Axiom, Oxygen forensik dan MOBILedit. kemudian tahap ini dimana akan mengajukan solusi yang dilakukan untuk pemecahan masalah dari hasil identifikasi masalah dan informasi hasil tahap pertama.

\subsection{Uji Coba}

Tahapan selanjutnya merupakan Proses uji coba tool forensik di mana tahapan ini untuk mendapatkan bukti digital yang kemudian digunakan sebagai pemecahan masalah yang dihadapi. tahapan percobaan tool forensik pada penelitian ini adalah sebagai berikut :

\subsubsection{Uji Coba dengan Belkasoft}

Tahapan uji coba yang digunakan pada tahap ini yaitu tool pertama yang akan di uji coba kan adalah dengan menggunakan aplikasi Belkasoft. Pada Proses ekstraksi data menggunakan Belkasoft sangat mudah, yaitu smartphone harus terkoneksi dengan tempat tool Belkasoft di install yaitu komputer atau laptop.

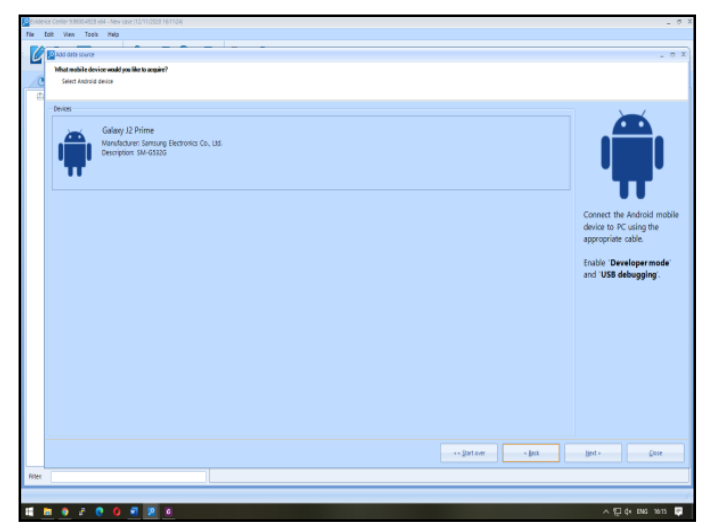

Gambar 5. Smartphone sudah terkoneksi dengan aplikasi Belkasoft

Gambar 5 yaitu menunjukkan telah terkoneksi smartphone dengan aplikasi Belkasoft. Sehingga smartphone dapat di akuisisi oleh aplikasi Belkasoft. Setelah terhubungnya smartphone dengan Belkasoft, langkah selanjutnya adalah di lakukan proses ekstraksi data kurang lebih sekitar 5 jam . Belkasoft dapat mengembalikan data multimedia berupa audio dan video yang telah dihapus. Tampilan hasil proses ekstraksi data oleh Belkasoft dapat ditunjukkan pada gambar 6 .

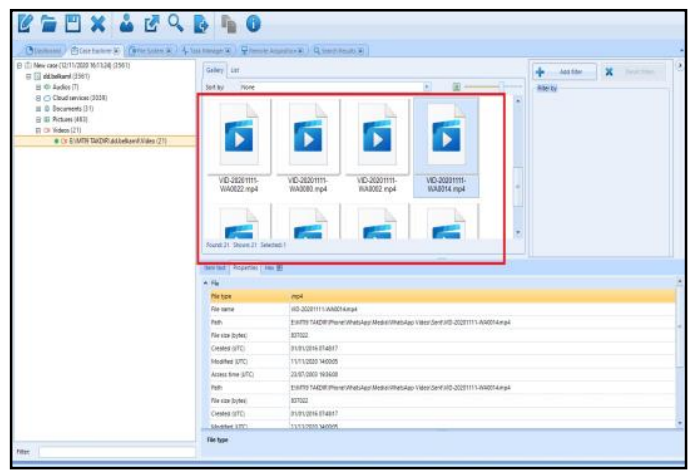

Gambar 6. Hasil ekstraksi menggunakan aplikasi Belkasoft 


\subsubsection{Uji coba dengan Oxygen}

Tahapan uji coba tool berikutnya yang digunakan pada penelitian ini yaitu Oxygen forensik. Penggunaan Oxygen forensik juga sama dengan aplikasi belkasoft membutuhkan koneksi komputer atau laptop tempat oxygen di install. Pada Gambar 7 menunjukan telah terkoneksinya smatphone dengan Oxygen.

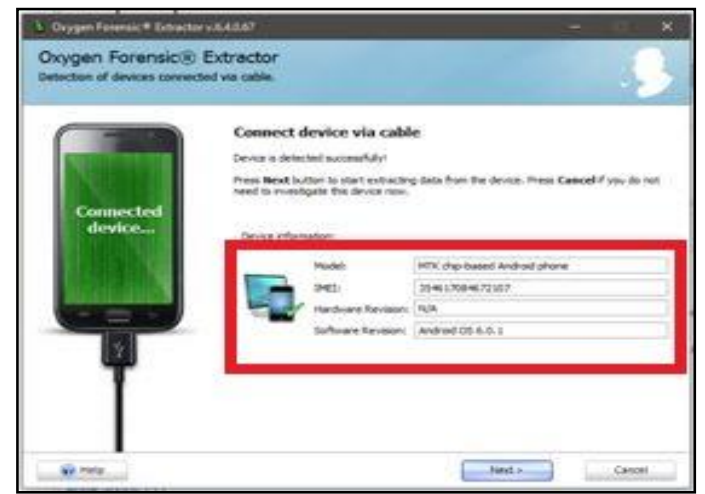

Gambar 7. Smartphone sudah terkoneksi dengan aplikasi Oxygen

Setelah terkoneksinya smartphone dengan aplikasi Oxygen, proses selanjutnya adalah langkah ekstraksi data. kemudian tool ini memperoleh hasil data multimedia berupa audio dan video yang terhapus dari smartphone dapat dilihat pada gambar 8 .

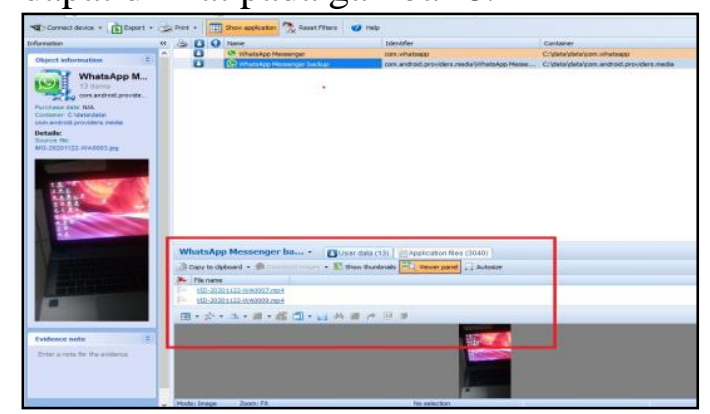

Gambar 8. Hasil ekstraksi menggunakan aplikasi Oxygen

\subsubsection{Uji coba dengan MOBILedit}

Tahapan uji coba tool ketiga yang digunakan pada penelitian ini yaitu MOBILedit. Penggunaan MOBILedit sama seperti Oxygen forensik yang juga membutuhkan koneksi laptop atau komputer tempat MOBILedit di install.

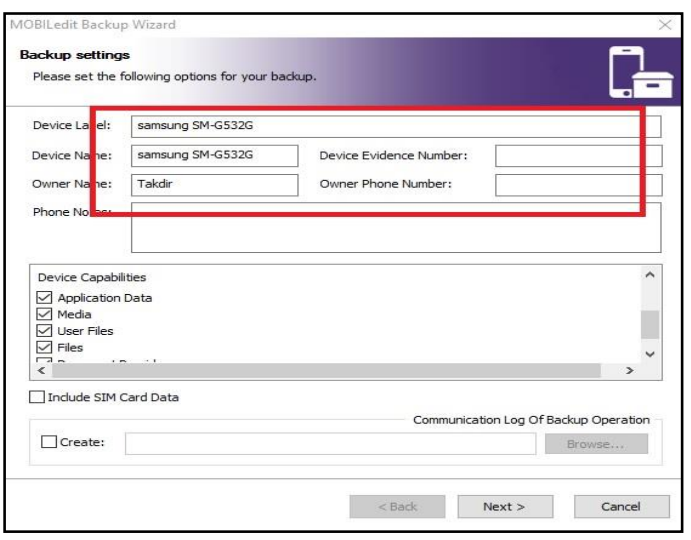

Gambar 9. Smartphone sudah terkoneksi dengan aplikasi MOBILedit

Gambar 9 yaitu menunjukkan Setelah terkoneksinya smartphone dengan aplikasi MOBILedit, selanjutnya akan dilakukan proses ekstraksi data untuk mengembalikan data yang ada pada perangkat smarphone android yang akan dijadikan sebagai barang bukti untuk mengungkap kasus penjualan narkoba secara online. Pada proses ekstraksi dengan MOBILedit, kemudian data yang terhapus tidak dapat dikembalikan. Tampilan hasil ekstraksi oleh MOBILedit ditunjukan pada gambar 10. 


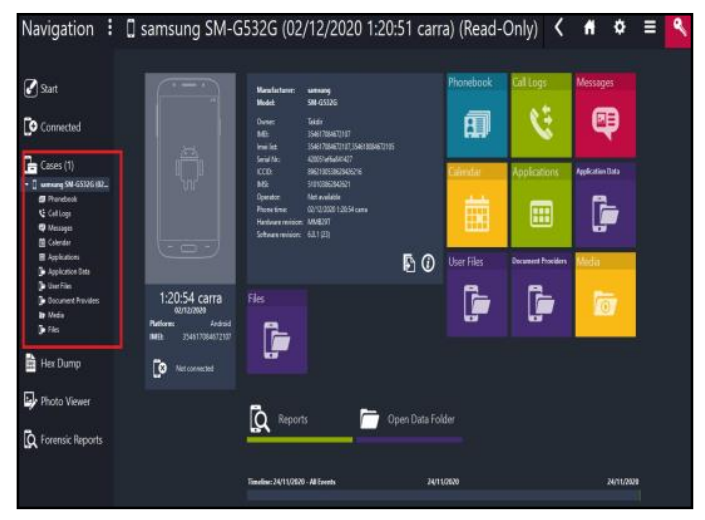

Gambar 10. Hasil Ekstraksi MOBILedit

\subsubsection{Uji coba dengan Magnet Axiom}

Tahapan uji coba tool berikutnya yang digunakan pada penelitian ini yaitu Magnet Axiom. Penggunaan Magnet Axiom sama seperti tool-tool sebelumnya yang juga membutuhkan koneksi laptop atau komputer tempat Magnet Axiom di install. Tetapi ada beberapa perbedaan yang signifikan dari aplikasi magnet axiom, Pada Gambar 11 menunjukan smatphone telah terkoneksi oleh Magnet Axiom.

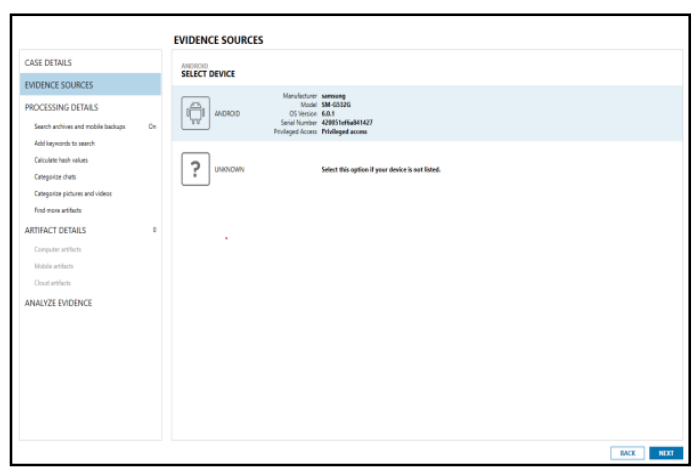

Gambar 11. Smartphone sudah terkoneksi dengan aplikasi Magnet Axiom

Setelah terkoneksinya smartphone dengan aplikasi Magnet Axiom, langkah selanjutnya yaitu proses ekstraksi data. ekstraksi dengan Magnet Axiom yaitu dapat mengembalikan data yang telah terhapus dan memperoleh hasil yang sangat signifikan. Hasil ekstraksi menggunakan aplikasi Magnet Axiom dapat dilihat pada gambar 12 .

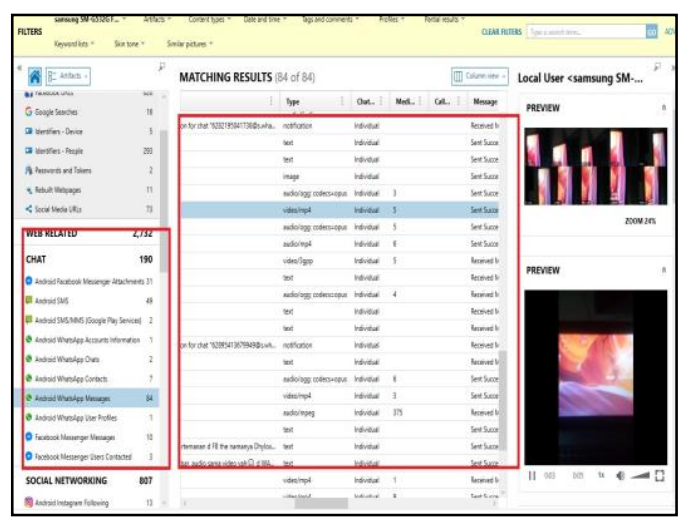

Gambar 12. Hasil Ekstraksi Magnet Axiom

\section{Evaluasi}

Tahapan evaluasi ini yaitu akan menyimpulkan hasil uji coba dari setiap tool yang digunakan dan mengevaluasi data yang sudah diperoleh. Tabel hasil evaluasi dapat dilihat pada Tabel 1.

Tabel 1. Hasil Evaluasi tool forensik

\begin{tabular}{|l|l|l|l|l|}
\hline \multicolumn{4}{|c|}{ Hasil Ekstraksi pada Samsung J2 prime } \\
\hline \multirow{2}{*}{ Tool } & \multicolumn{2}{|c|}{ WhatsApp } & \multicolumn{2}{c|}{ FB Messenger } \\
\cline { 2 - 5 } & Audio & video & Audio & video \\
\hline Belkasoft & Yes & Yes & Yes & Yes \\
\hline Oxygen & Yes & Yes & Yes & Yes \\
\hline MOBILedit & No & No & No & No \\
\hline Axiom & Yes & Yes & Yes & Yes \\
\hline
\end{tabular}

Pada tabel 1 di atas maka dapat di lihat belkasoft, Oxygen dan Magnet Axiom mampu mengembalikan data audio dan video yang terhapus sedangkan MOBILedit tidak bisa mengembalikan data audio dan video yang terhapus. 


\section{Laporan}

Tahap ini merupakan tahap hasil evaluasi, yang mencakup teknik, tool yang digunakan dan metodologi forensik yang dilakukan kemudian ada atau tidaknya tindakan, prosedur, pedoman, perangkat, dan aspek lain yang sekiranya diringkasan mengenai barang bukti dan prosedur forensik yang dilakukan serta perbandingan tool forensik yang digunakan. Informasi perangkat yang akan dilaporkan yaitu sebuah smartphone berbasis android dengan rincian merk dan jenis OS Android nya : Samsung, Model: Nomor Model : SM-G532G, J2 prime, OS : Android, Versi OS : 6.0.1 Lollipop. Data terhapus yang akan dikembalikan yaitu data audio dan video, dan tool yang digunakan adalah Belkasoft, Oxygen, MOBILedit dan Magnet Axiom.

\section{KESIMPULAN}

Dari Hasil yang didapatkan pada penelitian ini, mengenai forensik multimedia aplikasi instant messaging berbasis mobile menggunakan metode national institute of justice (NIJ), memberikan kesimpulan yaitu Data multimedia berupa audio dan video pada WhatsApp dan Facebook messenger yang telah terhapus pada perangkat smartphone android masih bisa dikembalikan menggunakan aplikasi Belkasoft, oxygen dan Magnet Axiom dan dari keempat tool yang di gunakan magnet axiom cukup baik dalam mengembalikan data yang terhapus, karena Magnet Axiom mampu mengangkat barang bukti audio dan video hampir $100 \%$.

\section{DAFTAR PUSTAKA}

Aditya, R., \& Wardhana, A. (2016). Pengaruh perceived usefulness dan perceived ease of use terhadap behavioral intention dengan pendekatan Technology Acceptance Model (TAM) pada pengguna Instant Messaging LINE di Indonesia. Jurnal Siasat Bisnis, 20(1), 24-32. https://doi.org/10.20885/jsb.vol20.i ss1.art3

Asyaky, M. S. (2019). Analisis dan Perbandingan Bukti Digital Aplikasi Instant Messenger Pada Android. Jurnal \& Penelitian Teknik Informatika, Vol. 3 No(1), 220-231.

Bakti Kominfo. (2019). BAKTI Dampak Positif dan Negatif Perkembangan Teknologi Komunikasi di Era Digital. https://www.baktikominfo.id/en/inf ormasi/pengetahuan/dampak_positi f_dan_negatif_perkembangan_tekn ologi_komunikasi_di_era_digital806

Databoks. (2020). Pengguna Smartphone diperkirakan Mencapai 89\% Populasi pada 2025 | Databoks. 
https://databoks.katadata.co.id/data publish/2020/09/15/penggunasmartphone-diperkirakanmencapai-89-populasi-pada-2025 detiknet. (2020). Riset: Ada 175,2 Juta Pengguna Internet di Indonesia. https://inet.detik.com/cyberlife/d4907674/riset-ada-1752-jutapengguna-internet-di-indonesia

Faiz, M. N., Umar, R., \& Yudhana, A. (2016). Analisis Live Forensics Untuk Perbandingan Kemananan Email Pada Sistem Operasi Proprietary. ILKOM Jurnal Ilmiah, 8(3), 242-247. https://doi.org/10.33096/ilkom.v8i3 .79.242-247

Nur Faiz, M., Adi Prabowo, W., \& Fajar Sidiq, M. (2018). Studi Komparasi Investigasi Digital Forensik pada Tindak Kriminal. Journal of Informatics, Information System, Software Engineering and Applications (INISTA), 1(1), 63-70. https://doi.org/10.20895/INISTA.V $1 \mathrm{I} 1$

Parlika, R., \& Hutama, D. S. (2019). Studi Komparatif Implementasi Push Message Pada Media Sosial Secara Gratis. E-NARODROID, $V(2)$.

Putra, R. A., Fadlil, A., \& Riadi, I. (2017). Forensik Mobile Pada Smartwatch Berbasis Android. Jurnal Rekayasa Teknologi Informasi (JURTI), 1(1), 41-47. https://doi.org/10.30872/JURTI.V1 I1.638

Raharjo, B. (2013). Sekilas Mengenai Forensik Digital. Jurnal Sosioteknologi, 12(29), 384-387. https://doi.org/10.5614/sostek.itbj.2

\subsection{2 .29 .3}

Riadi, I., Sunardi, S., \& Sahiruddin, S. (2019). Analisis Forensik Recovery pada Smartphone Android Menggunakan Metode National Institute Of Justice (NIJ). Jurnal Rekayasa Teknologi Informasi (JURTI), 3(1), 87-95.

Riadi, I., Umar, R., \& Firdonsyah, A. (2017). Identification Of Digital Evidence On Android's Blackberry Messenger Using NIST Mobile Forensic Method. International Journal of Computer Science and Information Security, 15(5), 3-8.

Riadi, I., Umar, R., \& Nasrulloh, I. M. (2018). Analisis Forensik Digital Pada Frozen Solid State Drive Dengan Metode National Institute of Justice (Nij). Elinvo (Electronics, Informatics, and Vocational Education), 3(1), 7082.

https://doi.org/10.21831/elinvo.v3i 1.19308

Riadi, I., Yudhana, A., Caesar, M., \& Putra, F. (2018). 1490-Article Text2859-1-10-20190413. Akuisisi Bukti Digital Pada Instagram Messenger Berbasis Android Menggunakan Metode National Institute Of Justice (NIJ), 4, 219227.

Sidiq, M. F., \& Faiz, M. N. (2019). Review Pencarian Bukti Digital dengan Metode Live dan Static Forensics pada Aktivitas Web Browser . doc ".

Siregar, H. F., \& Melani, M. (2019). Perancangan Aplikasi Komik Hadist Berbasis Multimedia. Jurnal Teknologi Informasi, 2(2), 113. 
https://doi.org/10.36294/jurti.v2i2.4 25

Umar, R., Riadi, I., \& Zamroni, G. M. (2018). Mobile forensic tools evaluation for digital crime investigation. International Journal on Advanced Science, Engineering and Information Technology, 8(3), 949-955.

https://doi.org/10.18517/ijaseit.8.3. 3591

Widodo, D., Raya, P. J., \& Purwokerto, D. (2018). Analisis Forensik Digital Aplikasi Whatsapp Dan Facebook Messenger Pada Android Sebagai Barang Bukti Digital Dalam Penanganan Kasus Prostitusi
Online Digital Forensic Analysis of Whatsapp and Facebook Messenger Application on Android As Digital Evidence G. Jurnal Respository, 12, 1-15.

Yudhana, A., Riadi, I., \& Anshori, I. (2018). Analisis Bukti Digital Facebook Messenger Menggunakan Metode Nist. It Journal Research and Development, 3(1), 13-21. https://doi.org/10.25299/itjrd.2018. $\operatorname{vol} 3(1) .1658$

Zamroni, G. M., Umar, R., \& Riadi, I. (2016). Analisis Forensik Aplikasi Instant Messaging Berbasis Android. 2(1), 102-105. http://ars.ilkom.unsri.ac.id 